USING TRANSISTORS 


\section{USING TRANSISTORS}

BY

D. J. W. SJOBBEMA

POPULAR SERIES

Macmillan Education 


\section{Translated by P. J. Arthern, London}

Publisher's note :

This book contains viii +131 pages and 142 illustrations

Other editions of this book in Philips Technical Library in the French, German, Spanish. Dutch and Danish language

U.D.C. Nr. $621.318 .57: 621.382 .3$

Original Dutch edition:

(C) N.V. Philips' Gloeilampenfabrieken, Eindhoven. The Netherlands, 1964 English edition:

(C) N.V. Philips' Gloeilampenfabrieken, Eindhoven. The Netherlands, 1964

Softcover reprint of the hardcover 1st edition 1964 978-0-333-00672-6

ISBN 978-1-349-81794-8 ISBN 978-1-349-81792-4(eBook)

DOI 10.1007/978-1-349-81792-4

First published in 1960

Second enlarged edition 1961

Reprinted 1961, 1963

Third enlarged edition 1964

Reprinted 1967, 1974

No representation or warranty is given that the matter treated in this book is free from patent rights; nothing herein should be interpreted as granting, by implication or otherwise, a licence under any patent rights. 


\section{FOREWORD}

Ten years after the announcement of its discovery, the transistor has ensured for itself an extremely important place in electronic techniques. This is due, to no small extent, to its special characteristics, which in many cases make the use of the transistor preferable to that of the thermionic valve. There are even applications in which the transistor has already completely or partially displaced the thermionic valve, in portable radio receivers, computers and satellites for example. The result is that a continually increasing number of technicians are being confronted with the transistor, either directly or indirectly.

The principal object of this book is thus to introduce technicians and students to the transistor, its specific characteristics and the present state of circuit techniques. With this object in view, the material is approached from the practical angle, so that the reader will find a number of hints on the construction and repair of transistor circuits, but no detailed mathematical treatment.

I should like to express my gratitude to Mr. P. J. Arthern for his English translation.

November 1959.

D. J. W. SJOBBEMA

\section{FOREWORD TO THE THIRD EDITION}

In the light of the rapid development of transistor techniques, I have not only revised the examples of chapter IX but also included an appendix giving a survey of certain other much used electronic components and a sketch of the manufacturing techniques in use at present.

D. J. W. SJOBBEMA

September 1964. 


\section{CONTENTS}

Chapter I.

Page

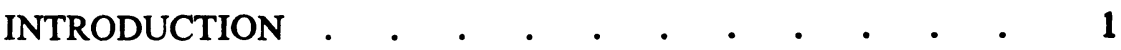

The construction of the junction transistor . . . . 2

The transistor compared with the thermionic valve. . 3

Chapter II.

BASIC PHYSICAL IDEAS . . . . . . . . . . . 6

The concept of semiconductors . . . . . . . .

Atomic linkages . . . . . . . . . . . . . .

$N$ germanium and $P$ germanium $\quad . \quad$. $\quad . \quad . \quad . \quad . \quad . \quad 12$

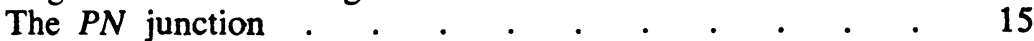

How a transistor works . $\quad . \quad . \quad . \quad . \quad . \quad . \quad . \quad . \quad 17$

Chapter III.

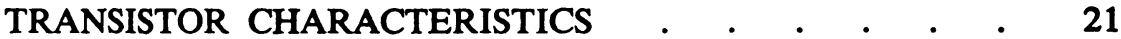

The three basic circuits . . . . . . . . 21

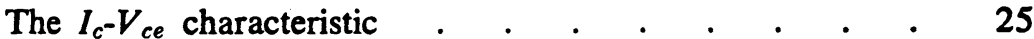

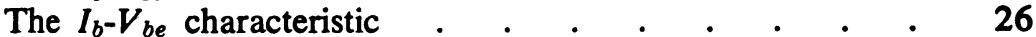

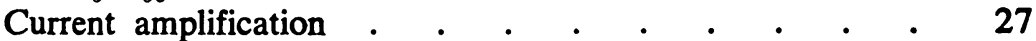

Voltage amplification . . . . . . . . . . . . 29

Power amplification . . . . . . . . . . . . . $\quad$. 31

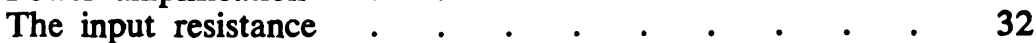

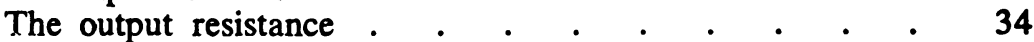

Chapter IV.

THE INFLUENCE OF TEMPERATURE CHANGES ON THE BEHAVIOUR OF TRANSISTORS . • • • • • • • • 36

Chapter V.

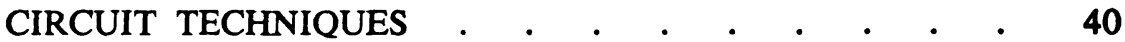

I. Amplifier circuits for audio-frequency signals . . . 40

Volume control . . . . . . . . . . . . 51

The output stage . $\quad . \quad$. $\quad . \quad$. $\quad . \quad$. $\quad . \quad$. 52

The class A output circuit $\quad . \quad$. $\quad . \quad$. $\quad . \quad$. 53

The push-pull circuit with two transistors in class B 56

The single-ended push-pull circuit . . . . . 60

Tone control . . . . . . . . . . . 62

Negative feedback. . . . . . . . . . . 64 
II. Amplifier circuits for radio-frequency signals . . . 66 Intermediate-frequency amplifiers . . . . . . 67

III. Oscillator circuits . . . . . . . . . . 70

IV. Mixer circuits . . . . . . . . . . . . . 71

V. Detector circuits . . . . . . . . . . . 73

VI. Automatic gain control . . . . . . . . 75

Chapter VI.

PRACTICAL HINTS FOR MOUNTING AND SERVICING

Chapter VII.

MEASUREMENTS . . . . . . . . . . . 81

1. Determination of the $I_{c}-V_{c e}$ characteristic . . . 81

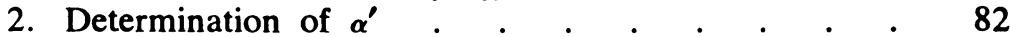

3. The $I_{b}-V_{b e}$ characteristic $\quad . \quad . \quad . \quad . \quad . \quad . \quad . \quad . \quad 83$

4. The input resistance . . . . . . . . . . $\quad . \quad 83$

5. The output resistance . . . . . . . . . . $\quad . \quad 84$

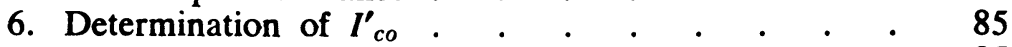

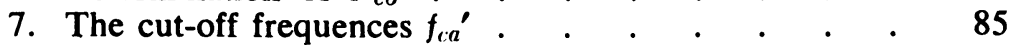

Chapter VIII.

PULSE TECHNIQUES . . . . . . . . . . . . 89

1. Circuit with battery and resistor . . . . . 89

2. Circuit with battery, resistor and capacitor . $\quad .90$

3. The differentiator network . . . . . . . 96

4. The transistor as a switch . . . . . . . 98

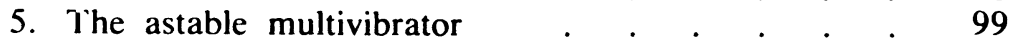

6. The bistable multivibrator . . . . . . . 101

7. The blocking oscillator . . . . . . 102

Chapter IX

EXAMPLES OF TRANSISTOR CIRCUITS . . . . . 105

1. A signal tracer . . . . . . . . . 105

2. A telephone amplifier . . . . . . . . 106

3. An internal telephone . . . . . . . . . 108

4. A hearing-aid with 4 transistors . . . . . 108 
5. An amplifier for children's gramophones

6. A $200 \mathrm{~mW}$ gramophone amplifier for use with a $6 \mathrm{~V}$ battery . . . . . . . . . . . 110

7. A 2.5 watt amplifier . . . . . . . . 114

8. Temperature control for an oil bath . . . . 115

9. A simple pocket-radio. . . . . . . . . 117

10. A portable battery receiver . . . . . . 117

11. A d.c. converter . . . . . . . . . . 119

12. A control relay using a photo-sensitive transistor . 121

13. A revolution çounter for petrol engines . . . . 122

14. A supply unit for 6 to $16 \mathrm{~V}, 0.7 \mathrm{~A}$. . . . 124

15. A sensitive d.c. voltmeter . . . . . . . 125 